\title{
PEMANFAATAN LIMBAH JAGUNG PAKAN SEBAGAI POC PADA TANAMAN JAGUNG MANIS
}

(Utilization of Feed Corn Waste as LOF on Sweet Corn Plants)

\author{
Tuti Herlinawati, Muhammad Rizal, Jamilatul Amalia, Mahdiannoor \\ Program Studi Agroteknologi STIPER Amuntai \\ Jl. Bihman Villa No. 123 Amuntai Kal-Sel 71417.Telp (0527) 6202 \\ Penulis Koresponden: tutilina889@gmail.com
}

Article Submitted : 30-12-2021

Article Accepted : 19-01-2022

\begin{abstract}
Feed corn is a new commodity developed in Balangan Regency. Some parts of this feed corn are not used and are just left alone by farmers who are classified as agricultural waste. This feed corn plant waste be used as a LOF. This LOF is used to increase the growth of sweet corn plants. This study aims (i) effect LOF waste corn feed on sweet corn plants. (ii)the best concentration. This research was conducted in Tabuan Village, Halong District, Balangan Regency, South Kalimantan Province from June - August 2021, using a single factor RBD. The factors studied were the application of LOF from corn waste feed (W) as much as 5 levels namely $\mathrm{w}_{1}=28.5 \mathrm{cc}$. plot ${ }^{-1}, \mathrm{w}_{2}=85.5 \mathrm{cc} \cdot \mathrm{plot}^{-1}, \mathrm{w}_{3}=142.5 \mathrm{cc} \cdot \mathrm{plot}^{-1}, \mathrm{w}_{4}=199.5 \mathrm{cc} \cdot \mathrm{plot}^{-1}, \mathrm{w}_{5}=$ 256.5 cc.plot ${ }^{-1}$. The results this study the LOF treatment of feed corn waste had a significant effect on plant variables aged 28 DAP, but had no effect on plant variables aged 14 and 21 DAP, length of cob with and without husks, the weight of cobs with and without husks. The best feeding corn waste POC was $1_{3}\left(142.5 \mathrm{cc}\right.$ plot $\left.^{-1}\right)$ of plant height and stem diameter at 28 DAP with $1_{1}\left(28.5 \mathrm{cc}_{\text {plot }}{ }^{-1}\right)$ on the variable number of leaves at $28 \mathrm{DAP}$.
\end{abstract}

Keywords: Feed corn, waste, POC, sweet corn.

\section{PENDAHULUAN}

Jagung merupakan tanaman dengan seribu manfaat, seluruh dari bagian tanaman jagung dapat dimanfaatkan. Manfaat pokok tanaman jagung adalah pemanfaatan biji jagung yang diolah makanan pokok. Selain itu limbah dari tanaman serba guna ini juga dapat dimanfaatkan untuk berbagai produk yang bernilai ekonomis seperti batang, daun dan tongkol jagung (Birawa, 2018).

Tahun 2018 Kabupaten Balangan tercatat mempunyai luas tanam jagung sebesar 5.276 ha dengan hasil produksi sebesar 23.535 ton. (BPS Kabupaten Balangan, 2018). Menurut Dinas Pertanian
Kabupaten Balangan (2019) Kabupaten Balangan mempunyai luas tanam jagung sebesar 18.917 ha dengan hasil produksi 107.477 ton/ha. Pada tahun 2020 Kabupaten Balangan memiliki luas tanam jagung sebesar 2.896 ha dengan hasil produksi 1.856 ton (Dinas Pertanian Kabupaten Balangan, 2019). Hal ini menunjukan bahwa tanaman jagung pakan sangat diminati dikalangan masyarakat, sehingga peluang produksi masih sangat besar.

Pemupukan merupakan

salah satu upaya guna meningkatkan produksi melalui pengoptimalan lahan yang sudah ada. Pupuk $\mathrm{N}$ merupakan pupuk yang dapat meningkatkan produksi tanaman tetapi jika 
tidak sesuai dalam Pengaturan dapat merugikan tanaman. Proses fotosintesis tidak berjalan maksimal jika kekurangan unsur $\mathrm{N}$ yang menyebabkan daun tanaman menguning, karena $\mathrm{N}$ termasuk unsur hara penyusun klorofil. (Nugroho, 2015).

Seresah jagung adalah limbah pertanian yang dihasilkan dari sisa-sisa tanaman jagung yang sudah dipanen., Kandungan limbah jagung 0,92\% N, 0,29\% $\mathrm{P}, 1,39 \% \quad \mathrm{~K}$ (Ruskandi, 2005). Hal ini menjadikan limbah jagung

yang diolah bahan organik dapat menambah kandungan unsur hara yang diperlukan tanaman.

Kandungan pupuk organik seresah jagung $0,81 \% \mathrm{~N}, 0,16 \% \mathrm{P}$ dan $1,33 \% \mathrm{~K}$ (Ernita et.al., 2017).

POC diharapkan mampu meningkatkan pertumbuhan dan kesuburan tanaman (Jumini et. al., 2012).

Penelitian bertujuan (i) guna mengetahui pengaruh pemberian POC limbah jagung pakan pada tanaman jagung manis (ii) mendapatkan konsentrasi terbaik pemberian POC limbah jagung pakan pada jagung manis.

\section{METODE PENELITIAN}

\section{Tempat dan Waktu}

Peubah Pengamatan

Tinggi. Diukur dari pangkal sampai ujung tanaman yang berumur 14, 21, 28 HST.

Diameter batang (mm). Diukur umur 14, 21 dan 28 HST menggunakan jangka sorong.

Jumlah daun pertanaman (helai). Dihitung pada umur 14, 21 dan 28 HST.

Panjang tongkol berkelobot (cm).

Diukur pada tanaman sampel .

Panjang tongkol tanpa kelobot (cm). Diukur dari pangkal buah sampai ujung buah ketika panen.

Berat tongkol berkelobot (g). Dengan menimbang seluruh tongkol berkelobot ketika panen.
Penelitian dilakukan di Desa Tabuan Kecamatan Halong Kabupaten Balangan Provinsi Kalimantan Selatan bulan Juni-bulan Agustus 2021.

\section{Bahan dan Alat}

a. Bahan yaitu POC limbah jagung pakan, air, pestisida, benih jagung manis Varietas Bonanza $f_{1}$ dan ATK.

b. Alat yaitu Cangkul, parang tugal, plang penelitian, meteran, gunting, gembor, ember, handsprayer, palu, gergaji, neraca digital dan kamera.

\section{Rancangan Percobaan}

Rancangan penelitian menggunakan metode eksperimen dengan RAK faktor tunggal. Faktor yang diteliti adalah pemberian berbagai konsentrasi POC limbah jagung pakan (L) sebanyak 5 taraf, yaitu :

$$
\begin{aligned}
& l_{1}=28,5 \text { cc.petak }{ }^{-1} \approx 0,71 \cdot \mathrm{ha}^{-1} \\
& \mathrm{l}_{2}=85,5 \mathrm{cc} \cdot \operatorname{petak}^{-1} \approx 0,751 \cdot \mathrm{ha}^{-1} \\
& \mathrm{l}_{3}=142,5 \mathrm{cc} \cdot \mathrm{petak}^{-1} \approx 0,81 \cdot \mathrm{ha}^{-1} \\
& \mathrm{l}_{4}=199,5 \mathrm{cc} \cdot \mathrm{petak}^{-1} \approx 0,851 \cdot \mathrm{ha}^{-1} \\
& \mathrm{l}_{5}=256,5 \mathrm{cc} \cdot \mathrm{petak}^{-1} \approx 0,91 \cdot \mathrm{ha}-1
\end{aligned}
$$

Setiap taraf perlakuan diulang 5 kali dan didapatkan 25 percobaan. Tiap percobaan terdiri 16 tanaman maka seluruhnya terdapat 400 tanaman dengan sampel yang diamati 4 tanaman, maka keseluruhan sampel adalah 100 tanaman sampel.

Berat tongkol tanpa kelobot (g). Ditimbang keseluruhan ketika panen.

\section{Analisis Data}

Setiap data perlakuan dianalisis dan dilakukan uji kehomogenan Bartlett, jika homogen dilanjutkan dengan Uji- ANOVA pada taraf $5 \%$. Setelah semua perhitungan ANOVA selesai, dilanjutkan dengan uji lanjutan untuk mendapatkan perlakuan terbaik.

\section{HASIL DAN PEMBAHASAN}

\section{Pertumbuhan Vegetatif}

Dari analisis ragam diketahui pemberian perlakuan POC limbah jagung pakan pada tanaman Jagung manis tidak 
berpengaruh di umur 14 dan 21 HST dan berpengaruh nyata di 28 HST. Rerata pertumbuhan vegetatif dapat di lihat Pada Tabel 1.

Tabel 1. Hasil rata-rata peubah vegetatif tanaman jagung umur 14, 21 dan 28 HST.

\begin{tabular}{|c|c|c|c|c|c|c|c|c|c|}
\hline \multirow{2}{*}{ Perlakuan } & \multicolumn{3}{|c|}{ Tinggi Tanaman $(\mathrm{cm})$} & \multicolumn{3}{|c|}{ Diameter batang (mm) } & \multicolumn{3}{|c|}{ Jumlah daun (helai) } \\
\hline & $14 \mathrm{HST}$ & $21 \mathrm{HST}$ & $28 \mathrm{HST}$ & $14 \mathrm{HST}$ & $21 \mathrm{HST}$ & $28 \mathrm{HST}$ & $14 \mathrm{HST}$ & $21 \mathrm{HST}$ & $28 \mathrm{HST}$ \\
\hline$l_{1}$ & 26.83 & 59.66 & $93.7^{\mathrm{b}}$ & 4.64 & 2.77 & $10.27^{\mathrm{a}}$ & 4.75 & 4.75 & $8.4^{\mathrm{bc}}$ \\
\hline $\mathrm{l}_{2}$ & 27.72 & 55.34 & $82.35^{\mathrm{a}}$ & 4.69 & 2.63 & $12.61^{\mathrm{b}}$ & 4.65 & 4.65 & $7.85^{\mathrm{ab}}$ \\
\hline$l_{3}$ & 30.46 & 60.71 & $96.5^{\mathrm{c}}$ & 5.17 & 2.19 & $13.84^{\mathrm{c}}$ & 4.75 & 4.75 & $8.55^{\mathrm{c}}$ \\
\hline $1_{4}$ & 26.37 & 62.31 & $96.2^{\mathrm{c}}$ & 4.80 & 2.35 & $10.07^{\mathrm{a}}$ & 4.65 & 4.65 & $8.25^{\mathrm{b}}$ \\
\hline 15 & 30.26 & 55.88 & $84.6^{\mathrm{ab}}$ & 4.29 & 2.30 & $10.70^{\mathrm{a}}$ & 4.5 & 4.5 & $7.4^{\mathrm{a}}$ \\
\hline
\end{tabular}

Keterangan : Nilai rata-rata yang diikuti huruf yang sama pada kolom yang sama menunjukan perlakuan tersebut tidak berbeda nyata berdasarkan DMRT pada taraf \%.

\section{Pertumbuhan Generatif}

Rata-rata analisis ragam menunjukan pemberian konsentrasi POC limbah jagung pakan tidak berpengaruh pada peubah panjang tongkol berkelobot dan tanpa kelobot, berat tongkol. Berkelobot dan tanpa kelobot. Rata-rata hasil generatif tanaman jagung manis dapat dilihat pada Tabel 2.

Tabel 2. Hasil rata-rata peubah generatif tanaman jagung manis.

\begin{tabular}{ccccc}
\hline Perlakuan & $\begin{array}{c}\text { Panjang Tongkol } \\
\text { Berkelobot }(\mathrm{cm})\end{array}$ & $\begin{array}{c}\text { Panjang Tongkol } \\
\text { Tanpa Kelobot }(\mathrm{cm})\end{array}$ & $\begin{array}{c}\text { Berat Tongkol } \\
\text { Berkelobot }(\mathrm{g})\end{array}$ & $\begin{array}{c}\text { Berat Tongkol Tanpa } \\
\text { Kelobot }(\mathrm{g})\end{array}$ \\
\hline$l_{1}$ & 30.9 & 2.59 & 385.75 & 267.2 \\
$l_{2}$ & 29.64 & 2.22 & 358.66 & 284.1 \\
$l_{3}$ & 31.13 & 2.55 & 390.45 & 277.8 \\
$l_{4}$ & 31.29 & 2.45 & 405.15 & 289.15 \\
$l_{5}$ & 29.63 & 2.49 & 373.65 & 2692.45 \\
\hline
\end{tabular}

Keterangan : Nilai rata-rata yang diikuti huruf yang sama pada kolom yang sama menunjukan perlakuan tersebut tidak berbeda nyata berdasarkan DMRT pada taraf $5 \%$.

\section{HASIL DAN PEMBAHASAN}

Analisis ragam memperlihatkan bahwa perlakuan POC limbah jagung pakan tidak berpengaruh di peubah tinggi tanaman, diameter batang dan jumlah daun umur 14 dan 21 HST, tapi berpengaruh nyata di umur 28 HST . Hal Ini diduga umur 14 dan 21 HST jagung manis belum mampu menyerap unsur hara karena tanaman masih tergolong muda. Menurut Mahdiannoor et. al., ( 2016), jagung manis sedang memasuki tahapan menjadi tanaman baru umur 14 serta 21 HST sehingga pertumbuhannya lambat.
Hasil analisis POC limbah jagung pakan menunjukkan bahwa kandungan unsur hara C-Organik rendah yaitu $0,057 \%$. Rendahnya kandungan C-Organik menyebabkan unsur hara makro yang terkandung dalam POC menjadi rendah. $\mathrm{C} / \mathrm{N}$ rasio rendah juga diduga menyebabkan tidak berpengaruhnya peubah Tinggi tanaman, parameter batang dan jumlah daun umur 14 dan 21 HST. Kurangnya perbandingan Corganik dan $\mathrm{C} / \mathrm{N}$ pupuk yaitu $3,35 \%$ mengakibatkan terjadinya hambatan penyerapan unsur hara oleh mikroba tidak dapat diserap dan hilang lewat udara sebagai 
$\mathrm{NH}_{3}$ (Ibrahim \& Tanaiyo, 2018). Peubah tinggi tanaman, diameter batang dan jumlah daun tidak berpengaruh umur 14 dan 21 HST, diakibat pupuk yang bersifat organik yang memerlukan waktu agar dapat terdekomposisi secara sempurna. Ini mengkibatkan unsur hara tidak tersedia dengan optimal sehingga tanaman tidak memberikan pertumbuhan yang optimal pada fase vegetatif. Munawar, (2005) menyatakan pupuk bokashi adalah pupuk yang sama dengan pupuk cair yang unsur hara dilepas secara perlahan dan terus menerus, sehingga unsur hara tidak secara cepat tersedia.

Tidak berpengaruhnya fase vegetatif tanaman jagung manis juga karena semua unsur hara di POC tidak memenuhi hingga pertumbuhan dan perkembangan tanaman terhambat. Terhambatnya pertumbuhan dan perkembangan tanaman dikarenakan kekurangan unsur hara makro dan mikro (Sutedjo , M. M., 1988). Kurangnya unsur hara $\mathrm{N}$ menyebabkan aktifitas pembelahan sel dan pembesaran sel menjadi terhambat yang menyebabkan tanaman menjadi kerdil sehingga pertumbuhan dan perkembangan tanaman jagung manis terganggu (Sianipar, 2019). Kekurangan unsur hara $\mathrm{P}$ juga menyebabkan rasio akar terhadap pucuk lebih besar. Kekurangan unsur K disebabkan $\mathrm{K}$ diangkut ke daun muda yang menimbulkan bercak transparan di daun (Matana dan Mashud, 2016). Hal ini menyebabkan proses fotosintesis terganggu karena proses fotosintesis terjadi pada daun.

Pemberian perlakuan POC limbah jagung pakan berpengaruh diumur 28 HST pada tinggi tanaman, diameter batang dan jumlah daun, diduga umur 28 HST tanaman jagung sudah bisa menyerap unsur hara untuk pertumbuhan umur 28 HST. Hal ini sejalan dengan pernyataan Atmaja (2017), Unsur hara N, P dan K membantu tanaman dalam mengoptimalkan fase vegetatifnya. Analisis tanah menunjukkan bahwa C-Organik sedang, N sedang, $\mathrm{P}$ sedang, $\mathrm{K}$ sedang dan $\mathrm{Fe}$ sedang dengan $\mathrm{pH}$ tanah yang masam. C-organik didalam tanah tergolong sedang, Corganik berguna untuk kesuburan tanah, menyuplai mikro hara dan faktor pertumbuhan lainnya (Darliana, 2009). Menurut Jurhana et. al., (2017) jika kebutuhan unsur hara terpenuhi maka akan menambah pertumbuhan tanaman jagung manis. Peningkatan tinggi dikarenakan unsur hara $\mathrm{N}$ mampu mempercepat pertumbuhan tinggi tanaman. Unsur hara $\mathrm{N}$ mempengaruhi pertumbuhan primer untuk berkembang (Setyamijaya, 1986). Zubachtirodin, (2008), mengatakan pemberian pupuk $\mathrm{N}$ mampu mengoptimal kan tinggi hingga $35 \mathrm{~cm}$ dibanding tidak diberi.

Unsur hara $\mathrm{N}$ juga berfungsi untuk pertambahan diameter batang, seperti pernyataan Gardner et. al., (1991), air dan N mempengaruhi aktivitas meristem lateral yang ditandai dengan bertambahnya diameter tanaman. pertumbuhan batang memperlihatkan luas penampang jaringan pengangkut hara pada tanaman. Unsur hara $\mathrm{N}$ juga berfungsi untuk pertambahan jumlah daun. Menurut Suwandi, (1987), POC dapat memacu pembentukan daun jika diberikan konsentrasi rendah. Tetapi POC memberikan hasil yang rendah jika diberikan dalam konsentrasi tinggi. Menurut Tjionger's (2006), penggunaan POC mampu mengurangi gugurnya daun dan meningkatkan pembentukan Daun yang bertujuan untuk proses fotosintat dan energi yang dihasilkan lebih tinggi.

Setiap perlakuan memberikan pengaruh berbeda pada fase vegetatif. Perbedaan tersebut diakibatkan kemampuan menyerap hara yang berbeda . Namun tanaman memiliki batas untuk menyerap hara. Seperti pendapat Lakitan,(1993),Perbedaan laju aktifitas jari ngan meristematik mengakibatkan pertum buhan tidak sama.

Kandungan $\mathrm{P}\left(\mathrm{P}_{2} \mathrm{O}_{5}\right)$ pada lampiran juga tergolong sedang, Fungsi $P$ yaitu 
mempercepat pertumbuhan akar, menstimulasi kerapatan akar dan memperkuat pertumbuhan tanaman muda menjadi dewasa (Bolly, 2018). Unsur hara $\mathrm{K}$ berfungsi untuk pengaturan penggunaan air, biosintesis protein, buka tutup stomata, dan pertukaran zat $\mathrm{N}$. Unsur hara $\mathrm{K}$ berperan sebagai bagian yangbersi fat higroskopis. Kandungan $\mathrm{pH}$ pada analisis tanah tergolong masam, derajat keasaman $(\mathrm{pH})$ berpengaruh terhadap aktifitas mikroba dan ketersediaan haradalam tanah. Jika tanah masam maka hara mikro sedikit (Haryanto, E., 2006). Pertumbuhan tanaman terhambat jika tanah masam. Seperti pendapat Saputro et. al., (2017). Unsur hara mudahdiser ap pada $\mathrm{pH}$ 6-7, karena pada kondisi tersebut UH mudah larut dalam air. Derajat keasaman tanah mengotentikasikan mudah tidaknya tanaman menyerap unsur hara Sebaliknya jika tanah masam, dapat mengganggu tanaman. Pemberian POC limbah jagung pakan tidak berpengaruh pada pertumbuhan generatif tanaman jagung manis disebabkan rendahnya kandungan unsur hara pada POC limbah jagung pakan. Kurang tersedianya $\mathrm{P}$ menjadi penyebab kecilnya ukuran tongkol jagung manis (Ernita et. al., 2017). Reaksi kemasaman tanah, Kadar $\mathrm{Al}$ dan $\mathrm{Fe}$ oksida juga menentukan ketersediaan $\mathrm{P}$ didalam tanah (Simanjuntak et. al., 2015). Hara K berperan untuk pembesaran buah dan kualitas buah, menentukan kualitas tongkol jagung dan mempercepat translokasi unsur hara (Hayati, 2006), karena pada fase tersebut tanaman membutuhkan hara $\mathrm{P}$ dan $\mathrm{K}$ (Ernita et. al., 2017). Tanaman jagung menghasilkan hasil yang baik apabila tercukupinya unsur hara bagi tanaman,

\section{KESIMPULAN}

1. POC limbah jagung pakan berpengaruh pada umur 28 HST (pertumbuhan vegetatif), tapi tidak berpengaruh di umur 14 dan 21 HST, panjang tongkol berkelobot dan tanpa kelobot, berat tongkol berkelobot dan tanpa kelobot.

2. Didapatkan konsentrasi POC limbah jagung pakan terbaik untuk peubah tinggi tanaman dan diameter batang $1_{3}(142,5$ cc.petak $^{-1}$ ) dan peubah jumlah daun adalah $1_{3}\left(28,5\right.$ cc. petak $\left.^{-1}\right)$.

\section{UCAPAN TERIMAKASIH}

Penelitian ini dibiaya oleh Direktorat Pembelajaran dan Kemahasiswaan; Direktorat Jendral Pendidikan Tinggi, Riset dan Teknologi; Kementerian Pendidikan, Kebudayaan, Riset dan Teknologi melalui Program Kreativitas Mahasiswa (PKM) dengan Nomor Kontrak 81/LL11/KM/2021 $\operatorname{tgl} 24$ Mei 2021.

\section{DAFTAR PUSTAKA}

Atmaja, I. S. W. (2017). Pengaruh Uji Minus One Test pada Pertumbuhan Vegetatif Tanaman Mentimun. Jurnal Logika, 19(1), 63-68.

BPS Kabupaten Balangan. (2018). Kabupaten Balangan Dalam Angka Tahun 2018.

Dinas Pertanian Kabupaten Balangan. (2021). Realisasi Tanam, Panen, Produksi dan Produktivitas Jagung Tahun 2019 dan 2020. Dinas Pertanian Tanaman Pangan.

Belfield, S., \& Brown, C. (2008). Field Crop Manual: maize - A Guide to Upland Production in Cambodia. NSW Department of Primary Industries. New South Wales, Australia.

Birawa, A. (2018). Raup Jutaan Rupiah dari Budidaya Jagung (Cetakan 1.). Jogjakarta: Trans Idea Publishing.

Bolly, Y. Y. (2018). Pengaruh Jarak Tanam dan Jumlah Benih Perlubang Tanam terhadap Pertumbuhan dan Hasil 
Tanaman Jagung Manis (Zea mays saccharata L.) Bonanza $\mathrm{F}_{1}$ di Desa Wairkoja, Kecamatan Kewapante, Kabupaten Sikka. Agrica, 11(2), 164178.

Darliana. (2009). Pengaruh Jenis Bokashi terhadap Bobot Isi, C-Organik dan KTK Tanah serta Hasil Daun Teh pada Andosol Asal Gambung. www.p4tkipa.org

Ernita, E. J., Yetti, H., \& Ardian, A. (2017). Pengaruh Pemberian Limbah Serasah Jagung terhadap Pertumbuhan dan Produksi Tanaman Jagung Manis (Zea mays saccharata Sturt). JOM FAPERTA, 4(2).

Gardner, F. P., Pearce, R. B., \& Mitchell, R. L. (1991). Fisiologi Tanaman Budidaya. Jakarta: Universitas Indonesia. UI Press). Terjemahan: Susilo dan Subiyanto.(P) LTD.

Haryanto, E., T. S. dan E. R. (2006). Sawi dan Selada. Jakarta: Penebar Swadaya.

Ibrahim, Y., \& Tanaiyo, R. (2018). Respon Tanaman Sawi (Brasicca juncea L.) terhadap Pemberian Pupuk Organik Cair (POC) Kulit Pisang dan Bonggol Pisang. Agropolitan, 5(1), 63-69.

Jumini, J., Hasinah, H., \& Armis, A. (2012). Pengaruh Interval Waktu Pemberian Pupuk Organik Cair Enviro terhadap Pertumbuhan dan Hasil Dua Varietas Mentimun (Cucumis sativus L.). Jurnal Floratek, 7(2), 133-140.

Jurhana, J., Made, U., \& Madauna, I. (2017). Pertumbuhan dan Hasil Tanaman Jagung Manis (Zea mays saccharata) pada berbagai Dosis Pupuk Organik. Agrotekbis: E-Jurnal Ilmu Pertanian, 5(3), 324-328.
Lakitan. (1993). Dasar-Dasar Fisiologi Tumbuhan. PT. Raja Grafindo Persada.

Mahdiannoor, M., Istiqomah, N., \& Syarifuddin, S. (2016). Aplikasi Pupuk Organik Cair terhadap Pertumbuhan dan Hasil Tanaman Jagung Manis. Ziraa'ah Majalah Ilmiah Pertanian, 4l(1), 1-10.

Matana, Y. R., \& Mashud, N. (2016). Respons Pemupukan N, P, K dan Mg terhadap Kandungan Unsur Hara Tanah. Buletin Palma, 16(1), 23-31.

Munawar. (2005). Kesuburan Tanaman dan Nutrisi Tanaman. IPB press, Bogor, 235.

Nugroho, W. S. (2015). Penetapan Standar Warna Daun sebagai Upaya Identifikasi Status Hara (N) Tanaman Jagung (Zea mays L.) pada Tanah Regosol. Planta Tropika: Jurnal Agrosains (Journal of Agro Science), 3(1), 8-15.

Pasta, A. E., \& Barus, H. N. (2015). Tanggap Pertumbuhan dan Hasil Tanaman Jagung Manis (Zea mays L. saccharata) pada Aplikasi berbagai Pupuk Organik. e-J. Agrotekbis, 3(2), 168-177.

Ruskandi. (2005). Teknik Pemupukan Buatan dan Kompos pada Tanaman Sela Jagung di antara Kelapa. Buletin Teknik Pertanian, 10(2).

Saputro, W., Sarwitri, R., \& Ingesti, P. S. V. R. (2017). Pengaruh Dosis Pupuk Organik dan Dolomit pada Lahan Pasir terhadap Pertumbuhan dan Hasil Tanaman Kedelai (Glycine max, L. merrill). VIGOR: Jurnal Ilmu Pertanian Tropika Dan Subtropika, 2(2), 70-73. 
Setyamijaya, D. (1986). Pupuk dan Pemupukan. CV. Simplek.

Sianipar, G. (2019). Respon Pertumbuhan dan Produksi Tanaman Kacang Tanah (Arachis hypogaea L.) terhadap Pemberian Kompos Batang Jagung dan Pupuk Organik Cair Limbah Ampas Tebu. Skripsi. Fakultas Pertanian. Universitas Medan Area.

Simanjuntak, W., Hapsoh, H., \& Tabrani, G. (2015). Pemberian Dolomit dengan Pupuk Fosfat terhadap Pertumbuhan dan Produksi Tanaman Kacang Tanah (Arachis hypogaea L.). JOM FAPERTA, 2(2).

Sutedjo , M. M., dan A. G. K. (1988). Pengantar Ilmu Tanah Terbentuknya Tanah dan Tanah Pertanian. Jakarta:
Bina Aksara.

Suwandi, N. N. (1987). Pengaruh Pupuk Biokimia Sari Humus pada Tanaman Kubis. Buletin Penelitian Hortikultura, 15(20), 213-218.

Tjionger's, M. (2006). Pentingnya Menjaga Keseimbangan Unsur Hara Makro dan Mikro untuk Tanaman. Jurnal Agrotropika, 1(4), 258-259.

Zubachtirodin, S. (2008). Peningkatan Efisiensi Pupuk N, P, K dan Produktivitas Jagung pada Lahan Kering Ultisol Kalimantan Selatan. Jurnal Penelitian Pertanian Tanaman Pangan, 27, 32-36. 